\title{
A (IN)APLICABILIDADE DA TEORIA DA OBJETIVAÇÃO OU ABSTRATIVIZAÇÃO DO CONTROLE DE CONSTITUCIONALIDADE DIFUSO NO BRASIL
}

\section{THE (IN) APPLICABILITY OF THE THEORY OF OBJECTIVATION OR ABSTRATIVIZATION OF THE CONTROL OF DIFFUSED CONSTITUTIONALITY IN BRAZIL}

\section{OSMAR VERONESE}

Doutor em Direito Constitucional pela Universidad de Valladolid, ES, Professor de Direito Constitucional da Universidade Regional Integrada do Alto Uruguai e das Missões - URI (Graduação e Mestrado/Doutorado), e do Instituto Cenecista de Ensino Superior de Santo Ângelo (IESA), Santo Ângelo/RS. Líder do Grupo de Pesquisa "Direitos de Minorias, Movimentos Sociais e Políticas Públicas", com registro no CNPQ, vinculado à linha de pesquisa Direito e Multiculturalismo, do Mestrado/Doutorado em Direito da URI/Santo Ângelo/RS. Procurador da República.

\section{MATHEUS WEISS PEREIRA}

Advogado, integrante do Grupo de Pesquisa "Direitos de Minorias, Movimentos Sociais e Políticas Públicas", com registro no CNPQ, vinculado à linha de pesquisa Direito e Multiculturalismo, do Mestrado/Doutorado em Direito da URI/Santo Ângelo/RS. Bacharel em Direito pela Faculdade Cenecista de Ensino Superior de Santo Ângelo. E-mail: weiss.p.matheus@gmail.com

\section{RESUMO}

O constituinte originário brasileiro optou pelo modelo de Constituição rígida, no qual 
o sistema de controle de constitucionalidade das leis objetiva averiguar se a norma infraconstitucional está em consonância com as diretrizes previstas no texto constitucional. $O$ presente artigo versa sobre 0 controle repressivo de constitucionalidade incidental, com ênfase no mecanismo constitucional que permite ao Senado Federal suspender a execução de lei declarada inconstitucional pelo Supremo Tribunal Federal e na verificação de aplicabilidade da teoria da objetivação do controle difuso no Direito brasileiro. O estudo analisa brevemente os sistemas repressivos de controle de constitucionalidade que influenciaram o sistema brasileiro, noticia aspectos históricos do controle pátrio, apresenta características processuais e o modo como é processada a arguição de inconstitucionalidade na via incidental, verifica a atuação senatorial no sistema difuso, e, ao fim, examina a possibilidade de o Supremo Tribunal Federal, de acordo com sua vontade, aplicar da teoria de objetivação no âmbito desse sistema.

PALAVRAS-CHAVE: Constituição Federal; Supremacia Constitucional; Controle de Constitucionalidade; Mutação Constitucional; Teoria da Objetivação

\section{ABSTRACT}

The Brazilian constituent opted for the rigid Constitutional model, in which the constitutionality control system of the laws aims to determine if the infraconstitutional norm is in line with the guidelines established in the constitutional text. This article deals with the repressive control of incidental constitutionality, with emphasis on the constitutional mechanism that allows the Federal Senate to suspend the execution of a law declared unconstitutional by the Federal Supreme Court and to verify the applicability of the theory of objectivation of diffuse control in Law Brazilian. The study briefly analyzes the repressive systems of constitutionality control that influenced the Brazilian system, notices historical aspects of the parental control, presents procedural characteristics and the way in which the argument of unconstitutionality is processed in the incidental way, verifies the senatorial performance in the diffuse 
system, and, in the end, it examines the possibility of the Federal Supreme Court, according to its will, to apply objectification theory within this system.

KEYWORDS: Federal Constitution; Constitutional Supremacy; Constitutionality Control; Constitutional Mutation; Theory of Objectivation.

\section{INTRODUÇÃO}

O controle judicial de constitucionalidade brasileiro prevê a convivência dos sistemas concentrado e difuso, além de uma série abrangente de ações, com arranjos capazes de intrigar não apenas aos jejunos, mas até os estudiosos nacionais do Direito Constitucional.

A matéria-prima destas reflexões, assim, é a Constituição do Estado, lei fundamental que organiza seus elementos essenciais, cujos pilares materiais são a aquisição e o exercício de poder e os direitos fundamentais. Embora o constitucionalismo encontre nesses temas seu núcleo, nunca se deve esquecer que as Constituições também refletem um tempo histórico, sistematizando valores e arranjos que a deram vida, sendo, assim, um produto da história e de seu tempo.

No objeto do estudo, a Lei Fundamental brasileira de 1988, de vocação democrática, limita e organiza os poderes do Estado, elenca direitos e garantias fundamentais, estabelece linhas gerais para a produção normativa, constituindo-se, assim, em parâmetro fundamental de coerência normativa e valorativa de um Estado Democrático de Direito.

Uma Constituição ampla regulando uma sociedade complexa se constitui em uma fonte de conflitos, razão pela qual os meios destinados a solver as controvérsias são imprescindíveis para a preservação do texto constitucional. É nessa perspectiva que se insere a presente reflexão, na medida em que, motivado pela defesa dos valores constitucionalizados, ganha impulso o fenômeno da "teoria da objetivação ou abstrativização do controle difuso de constitucionalidade", 
questionando-se os limites que o Supremo Tribunal Federal tem para alterar o significado de um dispositivo constitucional, a fim de conferir eficácia geral às decisões por ele proferidas em controle de constitucionalidade incidental, em cotejo com a competência constitucionalmente conferida ao Senado Federal.

Ao argumento de impulsionar a defesa dos direitos e garantias constitucionais, a Corte Máxima do país vem modificando, a partir de casos concretos, o exercício de sua jurisdição constitucional, para ampliar seus poderes, entrando em rota de colisão com outros dispositivos constitucionais instituídos pelo legislador constituinte.

No recorte específico, este artigo tem o escopo de analisar a aplicabilidade ou não da teoria da objetivação ou abstrativização do controle de constitucionalidade difuso no direito brasileiro, ou seja, se é possível o Supremo Tribunal Federal, utilizando-se de sua posição de intérprete constitucional, produzir eventual mutação do art. 52, inciso X, da Constituição Federal de 1988, alterando a função do Senado no controle difuso de constitucionalidade. É possível ou perigosa essa transfiguração do texto, alterando a literalidade legada pelo poder constituinte originário, expressão máxima da soberania popular?

Em busca de respostas, na primeira parte serão expostas as linhas mestras do sistema brasileiro de fiscalização constitucional, seu surgimento e evolução, dando-se ênfase ao modelo difuso de controle de constitucionalidade.

Em seguida, a atenção se volta ao processamento da arguição de inconstitucionalidade na sistemática incidental pátria, com suas peculiaridades a depender da instância judicial de sua arguição.

Por fim, com base nos julgamentos da Reclamação no 4.335/AC e nas ADIs no 3.470 e no 3.406 , será analisada a (in)adequação da teoria da objetivação do controle difuso no ordenamento jurídico brasileiro, especialmente examinando os argumentos expostos pelo Min. Gilmar Mendes, que trata pormenorizadamente da trajetória do STF a respeito da teoria em foco. Se não por outras razões, esta investigação se justifica por envolver a análise da supremacia constitucional, da função jurisdicional e dos mecanismos de defesa e preservação do texto normativo 
mais caro ao ordenamento jurídico pátrio, a Constituição.

\section{O SISTEMA BRASILEIRO DE CONTROLE DE CONSTITUCIONALIDADE DAS LEIS}

Os Estados Democráticos de Direito se caracterizam pela existência, ao lado do órgão encarregado da produção normativa, de um órgão estatal independente ao qual o próprio texto constitucional atribua competência para verificação da conformidade das normas ordinárias com seus princípios e regras. ${ }^{1}$

Nesse sentido, é pertinente estudar, ainda que de maneira sumária, o sistema repressivo-judicial de controle de constitucionalidade das leis, importante criação do direito constitucional e da ciência política do mundo moderno, cuja ideia central repousa na supremacia da Constituição sobre o ordenamento jurídico e, também, no caso brasileiro, de rigidez constitucional e proteção dos direitos fundamentais.

Antes disso, vale noticiar que o controle de constitucionalidade adotado no Brasil possui peculiaridades que o tornam único. Aqui se conjugam os modelos difuso ou norte-americano, que permite a todos os órgãos do Poder Judiciário a realização do controle incidental da constitucionalidade de leis e atos normativos, e concentrado ou austríaco, em que o órgão máximo do Poder Judiciário realiza abstratamente o controle de constitucionalidade das normas jurídicas. Veja-se um pouco de sua formação.

No período do Brasil Império, época de vigência da Constituição de 1824, o

\footnotetext{
1 Não se desconhece a importância dos debates envolvendo constitucionalismo e poder, em sociedades complexas como a brasileira, embora o enfoque deste artigo possua um recorte mais específico. Na dimensão mais abrange, vale noticiar: "Las nuevas defensas de la libertad del indivíduo están en la sociedade civil y no sólo en terreno institucional: son las autonomías locales, las asociaciones, el equilibrio entre las distintas clases y los distintos estamentos con sus opuestas mentalidades, la distinción entre el poder espiritual y el temporal. El pluralismo forma así parte integrante del constitucionalismo, y a la nueva democracia liberal de Tocqueville y Mill le conviene más bien la definición de constitucionalismo pluralista, ya que un <gobierno> libre se basa en una <sociedad> libre" (MATTEUCCI, 1998, p. 283).
} 
ordenamento jurídico brasileiro era carente de um mecanismo capaz de fiscalizar a constitucionalidade das leis, havendo um estado de cegueira que impedia a verificação de possível inconstitucionalidade. A influência francesa ensejou que se outorgasse ao Poder Legislativo a atribuição de fazer leis, interpretá-las, suspendêlas e revogá-las, bem como velar pela guarda da Constituição. No Estado Imperial unitário, não havia espaço para uma fiscalização independente realizada pelo Poder Judiciário. Nesse sentido, Neto e Sarmento apontam que

[...] a Carta de 1824 não contemplou qualquer mecanismo de controle judicial de constitucionalidade das leis. A única referência expressa ao controle de constitucionalidade é feita para atribuir a função ao próprio Poder Legislativo: caberia à Assembleia promover a "guarda da Constituição" (art. 13, IX). A única possibilidade de controle externo ao Legislativo era o emprego de prerrogativa imperial, inerente ao Poder Moderador, de interferir nos demais poderes (2014, p. 102-102).

Com o fim do Império e o advento da República, os ares constitucionais norte-americanos sopraram sobre o Direito brasileiro, o que resultou na criação do controle de constitucionalidade incidental, no qual se atribuiu a todos os órgãos do Poder Judiciário, das esferas federais e estaduais, a competência para aferir a compatibilidade das leis com a Constituição. De acordo com Ramos (2009, p. 141 142), sob o regime constitucional de 1891 , o controle jurisdicional se fazia no bojo de processos judiciais comuns, onde não se tinha como objeto a fiscalização da constitucionalidade de leis ou atos normativos.

Nas palavras do autor:

[...] se indispensável precisar a validade ou não das normas a serem utilizadas na solução do caso, o juiz ou tribunal, como parte de seu mister ordinário, controlava a constitucionalidade dessas disposições. No entanto, essa fiscalização, de natureza incidental, figurava na fundamentação da decisão proferida pelo órgão judiciário, produzindo efeitos apenas para as partes, nos limites do caso concreto (RAMOS, 2009, p. 142).

Embora a criação de um mecanismo de controle de constitucionalidade tenha sido uma grande conquista para o ordenamento jurídico brasileiro, percebeu- 
se que ele apresentava uma limitação que impossibilitava uma jurisdição constitucional mais efetiva e uma integridade no Direito brasileiro. Isso porque, tendo - Brasil adotado o sistema da civil law, não havia no direito pátrio um sistema que vinculasse as demais instâncias do Poder Judiciário às decisões definitivas do Supremo Tribunal Federal em controle de constitucionalidade, o que no direito norteamericano era suprido pelo stare decisis. O imbróglio era a possibilidade de existência e validade de decisões conflitantes ou contraditórias sobre a constitucionalidade da mesma lei ou ato normativo.

Para não violar a essência do controle de constitucionalidade incidental, em que suas decisões produzem efeitos inter partes, a solução encontrada para tentar corrigir o problema relativo à falta de eficácia geral das decisões tomadas pelo Supremo foi a criação da suspensão senatorial na Constituição de 1934, a qual introduziu significativas alterações em nosso sistema de controle de constitucionalidade. Por esse mecanismo, uma lei declarada inconstitucional pelo Supremo Tribunal Federal, em controle incidental, poderia ter sua execução suspensa pelo Senado Federal, fazendo com que a lei não fosse mais aplicada, alcançando, portanto, os que não constam como parte no feito. Essa Constituição, no art. 96, esclarecia que não se cuidava de declaração de inconstitucionalidade proveniente de qualquer órgão do Poder Judiciário, mas do Supremo Tribunal Federal, cabendo ao Procurador-Geral da República comunicar a decisão ao Senado Federal para o exercício (discricionário) da reportada competência (RAMOS, 2009, p. 145)

Além disso, coerente com o espírito da época, a Constituição de 1934 trouxe mais algumas inovações, tais como: a) a inclusão da Ação Direta de Intervenção Federal - entendida por Paulo Bonavides (2013, p. 340-341) como a semente que germinou o controle de constitucionalidade abstrato; b) a exigência da maioria absoluta de votos para a declaração da inconstitucionalidade de lei pelos Tribunais, conhecida como reserva de plenário; e c) o cabimento de Mandado de Segurança contra ato manifestamente inconstitucional ou ilegal de qualquer autoridade que ameaçasse ou violasse direito certo e inquestionável. 
Em contrapartida, a Carta de 1937 foi responsável por um inequívoco retrocesso no sistema de controle de constitucionalidade brasileiro. Apesar de não ter introduzido qualquer modificação no modelo difuso de controle, preservando, inclusive, o quórum especial para a declaração de inconstitucionalidade nos tribunais, o constituinte criou um mecanismo que possibilitava ao Presidente da República ${ }^{2}$ submeter qualquer lei declarada inconstitucional a uma reanálise pelo Parlamento, caso entendesse como necessário para o bem-estar do povo, à promoção ou defesa de interesse nacional de alta monta (art. 96, parágrafo único). Se esse pedido fosse confirmado por $2 / 3$ dos presentes em cada Casa do Congresso, a decisão que tivesse declarado a inconstitucionalidade da lei era tornada sem efeito, sendo, consoante ensina Ramos (2009, p. 145), uma "demonstração de evidente falta de compromisso com o princípio da supremacia que Ihe deveria servir de suporte". Com esse expediente, nas palavras de Tavares, passou a ser constitucional a existência no ordenamento jurídico de uma lei contrária à Constituição, com vigência plena e imunidade contra sua violação pelo Judiciário, havendo, pois, uma espécie de inconstitucionalidade parcial de norma constitucional, relativamente à lei reprovada pelo Congresso Nacional (TAVARES, 2002, p. 244245).

O Texto Magno de 1946 reestabeleceu o que havia sido relativizado na Constituição antecedente, ou seja, devolveu-se a autoridade e definitividade de uma declaração de inconstitucionalidade transitada em julgado, inexistindo a possibilidade, contemplada na Constituição pretérita, de revisão das decisões judiciais por órgãos políticos.

A Emenda Constitucional nำ 16, do ano de 1965, ao lado da representação interventiva, inaugurou o modelo de fiscalização abstrata da constitucionalidade de leis federais e estaduais por meio da Ação Direta de Inconstitucionalidade, de

\footnotetext{
2 Citando, Loewenstein, Neto e Sarmento (2014, p. 126-127) narram a situação em que o próprio Presidente editou um decreto-lei ( $\mathrm{DL} \mathrm{n}^{\circ}$ - 1.564/1939) cassando decisão do STF que exercera o controle de constitucionalidade sobre outro decreto-lei do regime, invocando o art. 180 da Carta, que Ihe permitia desempenhar as funções do Parlamento enquanto esse não se reunisse. Houve protestos no STF, mas, naturalmente, a posição do governo prevaleceu.
} 
competência do Supremo Tribunal Federal, tendo como único legitimado a propô-la o Procurador-Geral da República. Com efeito,

[...] a partir da entrada em vigor da EC no 16/65 o sistema de controle brasileiro, no que concerne ao aspecto modal ou procedimental, passou a combinar a técnica da declaração incidental, em concreto, consagrada no sistema modelar estadunidense, com o da fiscalização em abstrato da constitucionalidade de leis e atos normativos, de inspiração europeia (TAVARES, 2002, p. 146).

A Constituição Federal de 1967 e a de 1969, para os que consideram esta uma nova Lei Fundamental, não trouxeram inovações no sistema brasileiro de controle de constitucionalidade, ao menos do ponto de vista formal, porquanto as decisões, mesmo dos tribunais, foram tomadas sob espessa névoa democrática, em contexto de duvidosa legitimidade.

O mesmo, contudo, não pode ser dito em relação à atual Lei Fundamental, que ampliou significativamente os mecanismos de proteção judicial, e assim também o controle de constitucionalidade das leis. As inovações foram a criação da Ação Direta de Inconstitucionalidade por Omissão, da Ação Declaratória de Constitucionalidade (inserida por Emenda Constitucional), e a ampliação do rol de legitimados a proporem a Ação Direta de Inconstitucionalidade, conforme art. 103, hoje também responsáveis pela propositura da Ação Declaratória de Constitucionalidade, além do Mandado de Injunção, "acolhendo, de forma pioneira na história de nossas instituições fundamentais, instrumentos voltados à superação do fenômeno deletério da omissão inconstitucional de caráter normativo" (RAMOS, 2009, p. 152).

Com a ampliação da legitimidade, outorgando-se o direito de propositura a diferentes órgãos da sociedade, o constituinte pretendeu reforçar o controle abstrato de normas, fortalecendo e democratizando o sistema jurídico, a democracia e a supremacia dos direitos e garantias fundamentais previstos no texto constitucional que, "além de configurarem limites ao poder do Estado, são também uma parte da legitimação do próprio Estado, determinando seus deveres e tornando possível o 
processo democrático em um Estado de Direito" (MORAES, 2002, p. 578) Consoante se percebe, houve uma crescente ampliação dos mecanismos de controle de constitucionalidade no Brasil, com a adoção, em um primeiro momento, do sistema difuso, incidental ou norte-americano, evoluindo-se, gradativamente, para o acolhimento do sistema direto, abstrato ou europeu, compondo-se um sistema misto, de conciliação dos modelos concentrado e difuso, este objeto do próximo item.

\section{O EXERCÍCIO DO CONTROLE INCIDENTAL OU DIFUSO NO BRASIL}

O controle de constitucionalidade difuso, cuja importância mostra-se absolutamente relevante, uma vez que permite que juízes de primeiro grau e tribunais em suas composições plenárias realizem a filtragem constitucional (STRECK, 2002, p. 362), tem origem no direito estadunidense e a nomenclatura incidental, muito utilizada, revela a forma como a inconstitucionalidade é invocada e analisada em relação ao mérito. Depreende-se, pois, que a declaração de inconstitucionalidade da lei não é a pretensão primeira da parte no processo, mas, sim, o fundamento para alcançá-la. Trata-se de uma questão prejudicial ao mérito, na qual a verificação de constitucionalidade será um antecedente lógico, temporal e incidental para a formação do juízo acerca da controvérsia principal, revelando-se, portanto, "um instrumento de garantia dos direitos subjetivos do indivíduo" (SCARTEZZINI, 1994, p. 2).

Por ser apenas uma questão incidental analisada na fundamentação da decisão, amplia-se a legitimidade para provocá-la, não havendo previsão de um rol taxativo de legitimados, de modo que o simples interesse de agir confere legitimidade ativa para se arguir a inconstitucionalidade de determinada lei, mesmo não sendo autor ou réu no processo em que for suscitada. Nesse contexto:

O controle difuso aproxima a Jurisdição Constitucional e a sociedade. 
Disperso por todos os ramos do Judiciário, especialmente nas comarcas da Justiça Estadual Ordinária, o controle difuso tem o condão de incrementar o exercício da cidadania, robustecendo a noção de democracia, especialmente em países como o Brasil, com uma história constitucional tão atribulada. Assim, não são somente os tribunais, normalmente distantes, situados nas capitais dos Estados ou da República, que têm atribuição exclusiva para apreciação da constitucionalidade de leis e debates sobre a aplicação de leis e de atos normativos (CRUZ, 2004, p. 345).

Há, ainda, a possibilidade da inconstitucionalidade ser verificada de ofício pelo julgador, na medida em que, tomando conhecimento que a norma paramétrica para esse controle, a Constituição, está sendo desrespeitada, exsurge o dever do magistrado, como condutor cuidadoso do processo, de preservar os valores da Lei Maior e afastar o texto normativo infraconstitucional, verticalmente incompatível. É o que melhor se aproxima da noção de "sociedade aberta dos intérpretes da Constituição" (HÄBERLE, apud CRUZ, 2004, p. 345).

Embora o seu reconhecimento de ofício pelo julgador, ressalva-se o disposto no art. 10, do Código de Processo Civil, que estabelece a necessidade de oportunizar às partes que se manifestem sobre a matéria antes de ser proferida a decisão, sob pena de nulidade.

Além disso, o sistema incidental também é marcado pela ampla competência jurisdicional para exercê-lo, de maneira que qualquer juiz ou tribunal legalmente investido é competente para realizá-lo, essa é a razão pela qual é conhecido como controle difuso.

Outra característica que marca o controle incidental é a inexistência de um momento processual específico para ser arguida a inconstitucionalidade, que pode ocorrer nos momentos mais variados do processo, inclusive nos mais inesperados, como em uma petição avulsa juntada "[...] aos autos durante a tramitação da causa ou do recurso perante o órgão, ou até, se for o caso, em sustentação oral, na sessão de julgamento (MOREIRA, 2002, p. 29)".

No que diz respeito à amplitude do objeto sujeito ao controle, a via incidental abrange a fiscalização de atos normativos emanados de quaisquer dos Poderes, independentemente da hierarquia normativa do ato e do período em que editado, 
tampouco sob a vigência de qual Constituição foi produzido. Podem ser fiscalizadas, inclusive, as omissões legislativas que impossibilitam total ou parcialmente a aplicação da norma constitucional.

Ressalte-se, ainda, que a decisão proferida só atinge as partes integrantes do processo, porque, no curso de uma ação, a parte interessada objetiva a declaração da inconstitucionalidade da norma com finalidade de afastar a sua aplicação in concreto:

Não há a invalidação da lei, de modo geral, perante todos. A decisão afasta, apenas, a sua incidência no caso, para o caso e entre as partes. A eficácia da sentença é restrita, particular, refere-se, somente, à lide, subtrai a utilização da lei questionada ao caso sob julgamento, não opera erga omnes (VELOSO, 2003, p. 41).

Em outras palavras, o juízo decidirá tão somente para as partes que integram a lide, constituindo a sua decisão uma resposta à pretensão daquele que arguiu a inconstitucionalidade, o que dá ao controle difuso um viés de formalidade (NASCIMENTO, 2006, p. 39). A pronúncia de inconstitucionalidade não retira a lei do ordenamento jurídico, afasta apenas a sua aplicação. Quanto aos terceiros, não participantes da relação processual, a lei (atacada) continuará a ser aplicada, mesmo que esses terceiros supostamente se encontrem em situação jurídica semelhante à das partes da ação em que a inconstitucionalidade foi declarada.

Assentados, sucintamente e em linhas gerais, os principais aspectos do controle incidental de constitucionalidade, é momento de avançar para conhecer a forma de processamento da arguição de inconstitucionalidade no sistema de fiscalização normativa brasileiro.

\section{PROCESSAMENTO DA ARGUIÇÃO DE INCONSTITUCIONALIDADE NA SISTEMÁTICA INCIDENTAL}

Embora o controle incidental de constitucionalidade esteja presente no 
ordenamento jurídico pátrio desde a primeira Constituição Republicana, seu processamento foi disciplinado somente com o advento do Código de Processo Civil de 1973, nos arts. 480 a 482, matéria reprisada no atual Código de Processo Civil nos arts. 948 a 950.

Os diplomas citados restringem-se ao processamento do incidente de inconstitucionalidade perante os Tribunais, não havendo previsão de um procedimento especial a ser observado quando se estiver diante da primeira instância do Poder Judiciário. Nesse caso, a inconstitucionalidade da lei será processada da mesma maneira que outra questão prejudicial.

Tratando-se de inconstitucionalidade perante os tribunais, independentemente de ser Justiça Comum ou Especial, há de ser observada a chamada "regra de reserva de plenário", prevista no art. 97, da Constituição de 1988, a qual funciona como uma holding, de onde emana o fundamento que legitima as duas variantes do sistema de constitucionalidade brasileiro (STRECK, 2002, p. 371). Em obediência a esse comando constitucional, os tribunais somente poderão declarar a inconstitucionalidade de lei ou ato normativo pela maioria absoluta de seus membros ou dos membros de respectivo Órgão Especial (este, constituído na forma do art. 93, inc. XI, da Constituição). Está cláusula de reserva de plenário, segundo Moraes (2002, p. 590), "atua como verdadeira condição de eficácia jurídica da própria declaração jurisdicional de inconstitucionalidade dos atos do Poder Público, aplicando-se para todos os tribunais, via difusa, e para o Supremo Tribunal Federal, também no controle concentrado".

Consoante disposto no Código de Processo Civil de 1973, suscitada a inconstitucionalidade perante o tribunal, antes de remeter o processo à Turma ou Câmara, o relator deveria ouvir o Ministério Público, a não ser que este fosse o próprio suscitador da inconstitucionalidade. Com a entrada em vigor do Novo Código de Processo Civil, passou a ser necessário que o relator também ouça as partes antes da remessa do processo.

Remetido o processo à Turma ou Câmara, o colegiado analisará se acolhe ou rejeita a arguição de inconstitucionalidade. Rejeitando-a, segue o julgamento 
normal das demais matérias. Acolhendo-a, caberá ao Plenário ou Órgão Especial o conhecimento da arguição de inconstitucionalidade, enquanto as demais matérias resultam sustadas, ocorrendo, nesse momento, a chamada cisão funcional da competência, em que ao Plenário ou Órgão Especial cabe o julgamento da inconstitucionalidade, e à Turma ou Câmara, o julgamento das matérias remanescentes.

A reserva de plenário nada mais é do que um procedimento especial para a declaração de inconstitucionalidade pelos tribunais pátrios, os quais, ao julgarem matéria de sua competência, só declararão uma inconstitucionalidade arguida por maioria absoluta de votos e pelo plenário ou órgão especial, na forma do art. 97 , da Constituição Federal, em fórmula estabelecida para conferir maior segurança e estabilidade ao ordenamento jurídico, realçando o princípio da presunção de constitucionalidade das leis. A contrario sensu, a não implementação do referido quórum, "... implicará a aplicação da lei contestada como se fosse constitucional" (CLÈVE, 2000, p. 101).

O processamento do incidente é obrigatório, salvo: quando a questão constitucional já foi decidida pelo STF, ou seja, se há pronunciamento anterior a respeito da (in)constitucionalidade, há obrigatoriedade de vinculação ao precedente da Corte Maior; quando o Pleno ou Órgão Especial do Tribunal em que foi suscitada a inconstitucionalidade já tiver decidido anteriormente a mesma questão constitucional, "os órgãos fracionários ficam obrigados perante a decisão tomada pelo órgão qualificado (SARLET; MARINONI; MITIDIERO, 2017, p. 1022-1023)".

Não há incompatibilidade entre a Constituição e as exceções acima, consagradas por meio da Lei 9.756/1998, a qual apenas se moldou à construção jurisprudencial já consolidada no STF, uma vez que, existindo pronunciamento anterior sobre a constitucionalidade da norma por parte do Guardião da Constituição, incumbido de dar a última palavra em termos de interpretação constitucional, a adoção do mesmo entendimento pelo órgão fracionário prestigia a força normativa da Constituição. Há, atualmente, alinhamento entre a doutrina e o previsto no art. 949, par. único, do Código de Processo Civil. 
Assentados pontos importantes sobre o significado e o processamento do incidente de inconstitucionalidade de uma lei pela via difusa, passa-se ao exame do papel do Senado Federal na declaração de inconstitucionalidade do ato normativo (competência prevista no art. 52, X, da $C F / 88$ ) e a aplicabilidade da teoria da objetivação ou abstrativização no sistema incidental de constitucionalidade.

\section{SUSPENSÃo dA EXECUÇÃo dA leI PELO SENAdo E MUTAÇÃo CONSTITUCIONAL}

Consoante exposto, no controle incidental a inconstitucionalidade pode ser pronunciada por qualquer juiz ou tribunal do País, no decorrer de um caso concreto a ele submetido. Nesse contexto, a decisão terá eficácia inter partes, não dispondo de efeito erga omnes e vinculante em relação aos que não fazem parte da relação processual.

Entretanto, sendo a decisão proferida pelo STF, é possível ampliar os efeitos da declaração incidental de inconstitucionalidade por duas formas: aprovação de súmula vinculante ou suspensão da execução da lei por ato do Senado Federal, previsão esta introduzida no ordenamento jurídico pátrio pelo art. 91, inc. IV, da Constituição Federal de 1934.

Atualmente disciplinado no art. 52, inc. X, da Constituição Federal de 1988, esse mecanismo evita que outros interessados, no futuro, busquem o Judiciário para obter a mesma decisão, tendo em vista que o Senado Federal, discricionariamente, pode suspender a execução da lei, conferindo eficácia genérica à decisão definitiva, ou seja, "cuida-se de um ato político que empresta eficácia erga omnes à decisão do Supremo Tribunal proferida em caso concreto (BRANCO; MENDES, 2016, p. 1230)", uma vez que no estado federal, além de representar os estados federados, o Senado tem uma natural função modeladora, o que já justifica sua intervenção, podendo, a depender do caso, entender inoportuno ou inconveniente ampliar erga omnes o efeito decidido inter partes (BARROS, 2002, p. 604). 
Convém registrar, na esteira do pensamento de Clève (2000, p. 120) que o fato de 0 art. 52, X, referir-se unicamente à lei não permite concluir que o Senado esteja autorizado, apenas, a suspender a execução das leis em sentido formal. A expressão lei residente no referido comando constitucional sintoniza com o ato normativo de qualquer categoria declarado inconstitucional por decisão definitiva do Supremo Tribunal Federal, cabendo ao Senado, como órgão da federação, suspender a execução, igualmente, dos atos normativos estaduais, distritais e municipais.

Inexiste consenso em relação ao momento a partir do qual a execução da lei é suspensa pela resolução do Senado. A posição majoritária, destarte, é no sentido de que $o$ ato editado pelo Senado Federal produz efeitos prospectivos, ou seja, ex nunc, uma vez que suspender a execução da lei não pode significar retirar a eficácia da lei. Não fosse assim, não haveria diferença entre os controles concentrado e difuso, visto que suspender a vigência ou a execução da lei é como revogar a lei (STRECK, 2002, p. 377).

Com efeito, nos últimos anos vem ganhando força, no Direito Constitucional brasileiro, um movimento doutrinário e jurisprudencial que pretende redefinir o papel do Senado Federal, sustentando que o incidente de constitucionalidade proferido na via difusa (concreta), pela Suprema Corte, solitariamente, tem eficácia vinculante e erga omnes em face dos demais órgãos do Poder Judiciário, sendo desnecessária a edição de resolução pelo Senado Federal para suspender 0 ato normativo considerado inconstitucional.

A doutrina, ao discorrer sobre o tema, afirma que a exigência de que a eficácia geral da declaração de inconstitucionalidade proferida pelo Supremo Tribunal Federal, em casos concretos, dependa de decisão do Senado Federal, perdeu parte do seu significado com a ampliação do controle abstrato das normas, sofrendo um processo de obsolescência, estando inevitavelmente ultrapassada (BRANCO; MENDES, 2016, p. 1231).

Na seara jurisprudencial, a competência do Senado Federal foi, inicialmente, 
questionada no julgamento da Reclamação Constitucional no 4.335/AC ${ }^{3}$. Naquela oportunidade, os Ministros Gilmar Ferreira Mendes e Eros Grau sugeriram a dispensa da atuação do Senado Federal para que uma lei declarada inconstitucional no sistema incidental deixasse de ser aplicada para a generalidade. De acordo com a proposta do Min. Gilmar Mendes ${ }^{4}$, as decisões do STF que declarassem a inconstitucionalidade de uma lei na sistemática difusa produziriam os mesmos efeitos que as proferidas em controle abstrato, ou seja, erga omnes, restando ao Senado Federal a incumbência de dar publicidade a essas decisões.

À época, embora a plausibilidade e consistência da argumentação apresentada pelo Min. Gilmar Mendes, maior defensor da teoria da abstrativização ou objetivação do controle incidental (difuso) de constitucionalidade, prevaleceu o entendimento que a lei declarada inconstitucional incidentalmente produziria efeito inter partes e não vinculante.

Ocorre que, passados pouco mais de três anos, o Supremo Tribunal Federal voltou ao tema, por ocasião do julgamento ${ }^{5}$ das ADIs 3.406 e 3.470 (controle concentrado), que tratou da discussão acerca da proibição de normas que permitiam a extração, industrialização, comercialização e distribuição do uso do amianto na variedade crisotila, e, incidentalmente, declarou a inconstitucionalidade do art. $2^{\circ}$ da Lei Federal no 9.055/1955, entendendo que esta decisão, a partir de agora, também terá efeito vinculante e erga omnes.

A Corte, a partir da (nova) manifestação do Ministro Gilmar Mendes,

\footnotetext{
${ }^{3}$ BRASIL, Supremo Tribunal Federal. Reclamação n. 4335-AC; Relator: Ministro Gilmar Mendes. Julgado em: 20/03/2014 Disponível em: <www.stf.jus.br/imprensa/pdf/rc/4335eg.pdf>. Acesso em: 20 fev. 2018.

${ }^{4}$ Para o Ministro, com o surgimento do controle de constitucionalidade abstrato e a ampliação de seus legitimados ativos, não mais haveria motivo para a permanência da atribuição conferida ao Senado, cujo mecanismo considerou ultrapassado. Ele afirmou não ver coerência em uma decisão proferida pelo STF em controle abstrato possuir eficácia erga omnes, e outra decisão proferida pelo mesmo órgão e com mesmo quórum produzir efeitos meramente inter partes. Segundo seu entendimento, trata-se de um mecanismo de "[...] índole exclusivamente histórica", estando atualmente em desuso, razão pela qual sugeriu a materialização de uma mutação constitucional no dispositivo supracitado.

${ }^{5}$ BRASIL, Supremo Tribunal Federal. ADI 3406/RJ e ADI 3470/RJ; Relator: Ministra Rosa Weber. Julgado em 29/11/2017. Disponível em: http://www.stf.jus.br/arquivo/informativo/documento/informativo886. htm. Acesso em: 15 mar. 2018.
} 
entendeu ser necessário, a fim de evitar anomias e fragmentação da unidade, equalizar a decisão que se toma tanto em sede de controle abstrato quanto em sede de controle incidental, abandonando, pois, sua concepção tradicional. No novel julgamento, o Ministro Gilmar Mendes afirmou que o § 5º do art. 535 do Novo Código de Processo Civil 6 reforça esse entendimento, sendo, então, necessário fazer uma releitura do art. 52, X, da Constituição Federal, no sentido de que a Suprema Corte apenas comunica ao Senado Federal a decisão de declaração de inconstitucionalidade, para que a Casa Legislativa faça a publicação, isto é, intensifique a publicidade daquilo que foi decidido.

No mesmo sentido, o Ministro Celso de Mello afirmou que o Supremo Tribunal Federal realizou uma verdadeira mutação constitucional com a finalidade de expandir os poderes do Tribunal em relação à jurisdição constitucional. Segundo ele, a nova interpretação do art. 52, X, da Constituição Federal indica que o papel do Senado no controle de constitucionalidade é simplesmente o de, mediante publicação, divulgar a decisão do STF, uma vez que a eficácia vinculante já resulta da própria decisão da Corte.

A Ministra Cármen Lúcia, chancelando os votos acima referidos, afirmou que o Supremo Tribunal Federal está caminhando para uma inovação jurisprudencial, no sentido de não ser mais declarado inconstitucional cada ato normativo, mas a própria matéria que nele se contém. Derradeiramente, o Ministro Edson Fachin concluiu que a declaração de inconstitucionalidade, mesmo sendo incidental, opera uma preclusão consumativa da matéria, evitando que se caia numa dimensão semicircular progressiva e sem fim.

Com efeito, apesar de a teoria da abstrativização do controle difuso não ser

\footnotetext{
${ }^{6}$ Art. 535. A Fazenda Pública será intimada na pessoa de seu representante judicial, por carga, remessa ou meio eletrônico, para, querendo, no prazo de 30 (trinta) dias e nos próprios autos, impugnar a execução, podendo arguir: III - inexequibilidade do título ou inexigibilidade da obrigação; § 50. Para efeito do disposto no inciso III do caput deste artigo, considera-se também inexigível a obrigação reconhecida em título executivo judicial fundado em lei ou ato normativo considerado inconstitucional pelo Supremo Tribunal Federal, ou fundado em aplicação ou interpretação da lei ou do ato normativo tido pelo Supremo Tribunal Federal como incompatível com a Constituição Federal, em controle de constitucionalidade concentrado ou difuso.
} 
expressamente referenciada pela Suprema Corte no julgamento das referidas ações de inconstitucionalidade incidentais, é certo que o antigo entendimento foi superado, passando o STF a adotar a abstrativização do controle difuso diante de alegada ocorrência de mutação constitucional do art. 52, X, da Constituição Federal, e do "crescimento da tendência maximalista, no âmbito do controle de constitucionalidade brasileiro, que termina conferindo eficácia contra todos nos processos concretos, tomando seus efeitos idênticos àqueles inerentes à decisão produzida em sede de ação direta" (SILVA NETO, 2016, p. 53).

Conforme expõe a doutrina, o mecanismo da mutação constitucional "[...] permite a transformação do sentido e do alcance de normas da Constituição, sem que se opere, no entanto, qualquer modificação do seu texto (BARROSO, 2014, p. 146)", estando associada à plasticidade que algumas normas constitucionais detêm e à não observância de um mecanismo constitucional previsto, leia-se informal. De acordo com Hesse (2011, p. 98), a mutação constitucional, modifica "[...] de la manera que sea, el contenido de las normas constitucionales de modo que la norma, conservando el mismo texto, recibe una significación diferente". Trata-se, sem dúvida, de um mecanismo delicado, que deve observar alguns limites e fundamentos para se materializar, na medida em que se situa na confluência entre dois imperativos importantes do constitucionalismo democrático (NETO; SARMENTO, 2014, p. 343), o estático e o dinamismo:

O elemento estático consigna uma exigência indispensável à segurança jurídica, e evitando, ao menos em tese, a instabilidade institucional, procura salvaguardar os direitos e garantias fundamentais da pessoa humana; o elemento dinâmico propicia a adaptação das constituições às exigências do progresso, da evolução e do bem-estar social (BULOS, 1997, p. 73).

Esse meio de modificação constitucional manifesta-se lentamente com o decurso do tempo, quando o texto constitucional passa por uma modificação de sentido, por vezes imperceptível, podendo resultar de uma modificação na realidade fática ou de uma nova percepção do Direito. Entretanto, sempre deverá "[...] corresponder a uma demanda social efetiva por parte da coletividade (BARROSO, 
2014, p. 148)", leia-se necessidade, para ser legítima.

Havendo fundamento para materializar-se, e embora seja "[...] difícil determinar os limites da mutação constitucional, porque o fenômeno é, em essência, o resultado de uma atuação de forças elementares" (BULOS, 1997, p. 73), devem ser observados dois limites estabelecidos pela doutrina, a saber, (a) os limites semânticos do texto constitucional a se modificar o sentido; e (b) os princípios fundamentais da Constituição, considerando-se o sistema constitucional como um todo. Extrapolando um desses limites, tratar-se-á de uma mutação inconstitucional. Dessa forma, "um tribunal não pode mudar a constituição; um tribunal não pode 'inventar' o direito: este não é seu legítimo papel como poder jurisdicional, numa democracia" (LIMA; OLIVEIRA; STRECK, 2011).

Pelo exposto, com a devida venia, considera-se inaplicável o atual posicionamento do Supremo Tribunal Federal ao ordenamento jurídico pátrio, uma vez que o enunciado do art. 52, X, CF/88 - "suspender a execução, no todo ou em parte, de lei declarada inconstitucional por decisão definitiva do Supremo Tribunal Federal" -, na redação em que se encontra, não comporta sua leitura com o significado de publicar decisão definitiva do Supremo Tribunal Federal que declare inconstitucional uma lei, no todo ou em parte, eis que o ato interpretativo da Suprema Corte desvirtua a letra da norma que embasa a Constituição, quebrando a juricidade do princípio da separação dos poderes, sendo, então, uma mutação inconstitucional (BULOS, 1997, p. 135), manifestamente incompartível pelo programa da norma constitucional, que conduz à derrocada interna da Constituição por obra do seu órgão concretizador (CANOTILHO, 1998, p. 1101-1103).

Esse novo entendimento não trata de ampliar ou restringir a aplicação do sobrescrito dispositivo constitucional, agasalhando uma nova hipótese de incidência ou reduzindo-lhe uma, o que faz, na verdade, é, predatoriamente, impor-lhe uma aplicação totalmente diversa da prescrita. Trata-se de uma mutação inconstitucionalcanibal, que busca modificar a Constituição alimentando-se dela. Quando se pretende mudar a Constituição de uma maneira conflitante à semântica de seu texto, a via a ser adotada é a Emenda Constitucional. 
Outro argumento barrando a aplicação da teoria da objetivação ou abstrativização do controle de constitucionalidade difuso no Brasil é sua desnecessidade, ou, como dito pelo Min. Barroso (2014, p. 148), de "[...] demanda social efetiva por parte da coletividade", porquanto (a) o Senado Federal está em pleno uso de sua atribuição, e (b) se a execução da lei declarada inconstitucional não tenha sido suspendida pelo Senado, o STF pode utilizar-se do mecanismo da Súmula Vinculante, caso entenda necessário.

A título exemplificativo, a tese de que a atribuição do Senado Federal está ultrapassada e em desuso para suspender a execução de lei declarada inconstitucional cai por terra quando se verifica que do ano de 2007 até os dias de hoje, o Senado publicou mais de 30 Resoluções com fundamento no art. 52, X, da CF, dentre as quais, uma publicada em setembro de 2017 - Resolução n 15/2017 -, o que demonstra estar o Senado em pleno uso dessa atribuição.

Ante a existência do mecanismo constitucional da Súmula Vinculante, Lenio Streck (2013. p. 551) defende ser incabível a teoria da objetivação do controle difuso, pois se alcançaria o mesmo resultado atingido por uma Súmula Vinculante, por um procedimento facilitado. Para se aprovar uma súmula vinculante é necessário um quórum de dois terços dos Ministros do STF, "após reiteradas decisões sobre a matéria constitucional" (art. 103-A, da CF/88), o que difere em muito da proposta de se conferir eficácia erga omnes a uma decisão isolada por um quórum de maioria absoluta, como ocorreu no caso que originou as ADIs.

Ainda, caso se entendesse pela usurpação da competência do Senado Federal quanto à suspensão da execução de lei declarada inconstitucional, estar-seia a violar gravemente os direitos e garantias fundamentais e "o modelo autocrático de aplicação do direito, aqui com perigosos efeitos no plano da relação entre as funções estatais" (SILVA NETO, 2016, p. 53). Veja-se que, ao atribuir automaticamente efeitos erga omnes às decisões do STF em controle difuso, estarse-ia, por meio de um processo subjetivo e concreto, a atingir quem sequer participou dele para se defender, ferindo, por conseguinte, "[...] os princípios constitucionais do devido processo legal, da ampla defesa e do contraditório - art. 
5. ․ LIV e LV, da Constituição da República" (STRECK, 2013, p. 551).

De mais a mais, ocorreria um esvaziamento da sistemática mista de fiscalização da constitucionalidade das leis caso fosse aplicada. Se a Constituição prevê características que são próprias de cada meio de controle de constitucionalidade, que estão na essência de seus conceitos, não se pode desconsiderá-las, sob pena de igualá-los.

Sublinhe-se, ademais, que esse mecanismo de controle de constitucionalidade das leis, exercido por dois Poderes, é um dos que dá vida à teoria dos freios e contrapesos, ou seja, alimenta a necessária fiscalização de um poder por outro e reforça a separação dos Poderes, uma das maiores afirmações do Estado Constitucional, sendo necessário respeitar a separação dos poderes, preservando as competências do Poder Legislativo (AGRA, 2008). Vale lembrar, "para que não se possa abusar do poder, é preciso que, pela disposição das coisas, o poder detenha o poder" (MONTESQUIEU, apud SANTOS, 2009, p. 104).

Não soa razoável permitir, assim, que pela interpretação de uma matéria polêmica (quando votada não convenceu a maioria dos Ministros da Corte), o Supremo Tribunal Federal retire funções atribuídas pelo Constituinte Originário a outro Poder, adotando uma via a indicar um aumento da judicialização das relações sociais, algo a ser evitado no atual quadrante da história brasileira, até porque o "Poder Judicial sendo essencialmente o intérprete das leis, deve ter tão pouca iniciativa e personalidade quanto possível" (SANTOS, 2009, p. 1005). Conforme Kelsen, apoiado na Suprema Corte dos Estados Unidos "[...] a perfeição do sistema exige que as linhas que separam e dividem esses departamentos devam ser ampla e claramente definidas" (2000, p. 385).

Ainda, quanto ao argumento de que 0 art. 535, $\S 5^{\circ}$, do CPC estaria a reforçar a ideia de eficácia vinculante e erga omnes das decisões em controle difuso, não se pode olvidar que a Constituição pátria é dotada de rigidez e supremacia hierárquica. Há um procedimento específico para a sua alteração, que é bem mais rigoroso do que o previsto para elaboração das demais leis, sendo da essência do sistema pátrio que a Constituição não possa ser alterada por estas. É a interpretação 
das leis que deve ser conforme a Constituição, e não o inverso. De acordo com Silva Neto (2016, p. 54):

[...] a competência estatuída ao STF pelo art. 102, caput, da CF quanto à guarda da Constituição não repugna interpretá-la sistematicamente em face das demais prescrições constitucionais, de modo particular a que impõe o relacionamento independente e harmonioso entre as funções estatais legislativa, executiva e judiciária (art. $2^{\circ}$ da Constituição).

Conclui-se, portanto, pela impossibilidade de acolher a tese em comento, uma vez que o seu fundamento jurídico esbarra em obstáculos constitucionais intransponíveis, exceto se for aceita uma atuação discricionária, pragmática, ilegítima e atentatória à integridade do ordenamento jurídico, nos termos dos fundamentos acima expostos.

\section{CONCLUSÃO}

A partir do problema proposto, embasado no questionamento acerca da aplicabilidade da teoria da objetivação do controle de constitucionalidade difuso, bem como na supremacia e necessidade de preservação do Texto Constitucional, discorreu-se sobre a possibilidade de o Supremo Tribunal Federal ampliar, de acordo com sua vontade, os efeitos das decisões proferidas em controle de constitucionalidade pela via incidental.

Levando-se em conta as constantes transformações sociais, cotejadas com o princípio da supremacia da Constituição, o Constituinte Originário, com o intuito de evitar a fossilização da Lei Fundamental, a qual serve de guia a um País de contrastes, multicultural, previu claros mecanismos de alinhamento do texto ao passo do tempo, de acolhimento dos novos valores, sem que para tanto se percorra atalhos interpretativos e se desconsidere a rigidez constitucional.

Nessa senda, a via originária e ordinária de modificação constitucional é a Emenda Constitucional, não por acaso um método mais rigoroso para modificar a Lei 
Fundamental, disponível tão somente ao constituinte derivado. Posteriormente, seguindo apelos doutrinários e jurisdicionais, pavimenta-se o mecanismo informal de mudança da Constituição, conhecido como mutação constitucional, que na face mais conhecida em terras pátrias, resulta de nova interpretação dada pela Suprema Corte.

No presente estudo, a aplicação da teoria da objetivação ou abstrativização do controle de constitucionalidade difuso no ordenamento brasileiro baseia-se em uma eventual mutação constitucional do art. 52 , inciso X, da CF/88. Ocorre que, para a materialização de uma mutação constitucional, é imprescindível atender alguns requisitos, a saber, uma modificação na realidade fática ou uma nova percepção do Direito que justifique adequação da norma constitucional à nova realidade, bem como a observância dos princípios constitucionais e do limite semântico do dispositivo que se pretende alterar.

Em definitivo, não se vislumbra a conjugação desses fatores, tampouco uma situação de urgência que justifique a objetivação do controle difuso, ainda mais pelo obstáculo intransponível que é a literalidade do texto constitucional do inc. $\mathrm{X}$, do art. 52, da Constituição Federal de 1988.

Somando-se a isso, o constituinte derivado brindou a Corte Máxima com o mecanismo constitucional da súmula vinculante, que faculta, atendidos os requisitos constitucionais, conferir eficácia geral e vinculante a uma decisão originariamente de efeitos inter partes. Aplicar a teoria da objetivação do controle difuso, além de violar 0 art. 52, inc. $X$, é desconsiderar o dispositivo da súmula vinculante previsto no art. 103-A da CF de 1988, uma vez que se alcançaria o resultado de uma súmula vinculante por um procedimento facilitado, erosionando a separação dos poderes e a essência do Estado Democrático de Direito.

Enfim, embora a teoria estudada apresente resultados sedutores e a fórmula que viabiliza a participação do Senado encontra-se enfraquecida pela ampliação do controle abstrato e por diversas decisões do Supremo Tribunal Federal, em atenção à preservação de uma série de valores constitucionalizados, expostos no presente estudo, é prudente defender, ao menos por ora, sua inaplicabilidade nos termos 
propostos. Há mecanismos aptos a corrigir algum ponto dissonante entre texto e contexto constitucional à disposição, tanto do legislador, quanto do intérprete, impondo-se resistir à ideia de que uma análise pragmática seja suficiente para abrir um "puxado constitucional". Ademais, os mecanismos constitucionais vigentes são suficientes ao salutar funcionamento das funções do Estado, não impedindo a máxima efetividade dos comandos valorativos contemplados na Lei que refundou juridicamente nossa sociedade democrática.

\section{REFERÊNCIAS}

AGRA, Walber de Moura. Aspectos controvertidos do controle de constitucionalidade. Salvador: Juspodivm, 2008.

BARROS, Sérgio Resende de. Simplificação do Controle de Constitucionalidade. In: As vertentes do direito constitucional contemporâneo. MARTINS, Ives Granda da Silva (Coord.). Rio de Janeiro: América Jurídica, 2002.

BARROSO, Luís Roberto. Curso de Direito Constitucional Contemporâneo: os conceitos fundamentais e a construção do novo modelo. 4. ed. São Paulo: Saraiva, 2014.

BONAVIDES, Paulo. Curso de Direito Constitucional. 28 ${ }^{\mathrm{a}}$ Ed. São Paulo: Malheiros: 2013.

BRANCO, Paulo Gustavo Gonet; MENDES, Gilmar Ferreira. Curso de Direito Constitucional. 12ª ed. São Paulo: Saraiva, 2016.

BULOS, Uadi Lammêgo. Mutação Constitucional. São Paulo: Saraiva, 1997.

BRASIL. Constituição da República Federativa do Brasil. Brasília, DF: Senado Federal, 1988.

$\begin{array}{ccccc} & \text { Supremo Tribunal Federal. Reclamação n. 4335-AC; Relator: Ministro } \\ \text { Gilmar } & \text { Mendes. Julgado } & \text { em: 20/03/2014. } & \text { Disponível em: }\end{array}$ <www.stf.jus.br/imprensa/pdf/rcl4335eg.pdf>. Acesso em: 20 fev. 2018.

. Supremo Tribunal Federal. ADI 3406/RJ e ADI 3470/RJ; Relator: Ministra Rosa Weber. Julgado em 29/11/2017. Disponível em: http://www.stf.jus.br/arquivo/informativo/documento/informativo886.htm. Acesso em: 
15 mar. 2018.

CANOTILHO, José Joaquim Gomes. Direito Constitucional e Teoria da Constituição. Coimbra: Livraria Almedina, 1998.

CLÈVE, Clèmerson Merlin. A fiscalização abstrata da constitucionalidade no direito brasileiro. $2^{\mathrm{a}}$ ed. São Paulo: Editora Revista dos Tribunais, 2000.

CRUZ, Álvaro Ricardo de Souza. Jurisdição constitucional democrática. Belo Horizonte, Del Rey, 2004.

LIMA, Martonio Mont'Alverne Barreto; OLIVEIRA, Marcelo Andrade Cattoni de; STRECK, Lenio Luiz. A nova perspectiva do Supremo Tribunal Federal sobre o controle difuso: mutação constitucional e limites da legitimidade da jurisdição constitucional. Disponível em: http://www.egov.ufsc.br/portal/conteudo/novaperspectiva-do-supremo-tribunal-federal-sobre-o-controle-difusomuta\%C3\%A7\%C3\%A3o-constitucional Acesso em: 29 mai. 2018.

HESSE, Konrad. Escritos de derecho constitucional. Trad. Pedro Cruz Villavón e Miguel Azpitarte Sánchez. Madrid: Centro de Estudios Políticos y Constitucionales, 2011.

MORAES, Alexandre de. Direito Constitucional. 11르 ed. São Paulo: Atlas, 2002.

KELSEN, Hans. Teoria Geral do Direito e do Estado. São Paulo: Martins Fontes, 2000.

MATTEUCCI, Nicola. Organización del poder y libertad. Madrid: Trotta, 1998.

MOREIRA, José Carlos Barbosa. Comentários ao Código de Processo Civil. 1. ed. eletrônica. Rio de Janeiro: Forense, 2002.

NASCIMENTO, Valéria Ribas do. Arguição de descumprimento de preceito fundamental: cegueira ou lucidez do controle concentrado de constitucionalidade? São Paulo: LTr, 2006.

NETO, Cláudio Pereira de Souza; SARMENTO, Daniel. Direito constitucional: teoria, história e métodos de trabalho. 2ª ed. Belo Horizonte: Fórum, 2014.

RAMOS, Elival da Silva. A evolução do sistema brasileiro de controle de constitucionalidade e a Constituição de 1988. In: Os 20 anos da Constituição da República Federativa do Brasil. MORAES, Alexandre de. (Coord.). São Paulo: Atlas, 2009.

SANTOS, André Leonardo Copetti. Elementos da Filosofia Constitucional. Porto 
Alegre: Livraria do Advogado, 2009.

SARLET, Ingo Wolfgang; MARINONI, Luiz Ghilherme; MITIDIERO, Daniel. Curso de Direito Constitucional. 6ª ed., São Paulo: Saraiva, 2017.

SCARTEZZINI, Ana Maria. A ação declaratória de constitucionalidade e os princípios constitucionais. In: Ação declaratória de constitucionalidade. MARTINS, Ives Granda da Silva; MENDES, Gilmar Ferreira. (Coord.). São Paulo: Saraiva, 1994.

SILVA NETO, Manoel Jorge e. O constitucionalismo brasileiro tardio. Brasília: ESMPU, 2016.

STRECK, Lenio Luiz. Jurisdição Constitucional e Decisão Jurídica. 3. ed. São Paulo: Revista dos Tribunais, 2013. . Jurisdição Constitucional e Hermenêutica: uma nova crítica do direito. Porto Alegre: Livraria do Advogado, 2002.

TAVARES, André Ramos. Curso de Direito Constitucional. São Paulo: Saraiva, 2002.

VELOSO, Zeno. Controle jurisdicional de constitucionalidade. 3. ed. Belo Horizonte: Del Rey, 2003. 